\title{
Are Foreign Securities A Safe Haven For A Rentier Economy? An Acceptability Framework from Surveys' Perspectives
}

\section{Mohammed Al-Homaidy}

Msc. Investment and Finance from Queen Mary university of London, MA in Economics from Kingston University London, Pgdip. Investment Management, Alexandria-Egypt and MA in Discourse Analysis Linguistics, University of Technology Sydney

\begin{abstract}
Toward answering a complicated question of considering financial low-risk and fixed income instruments a safe haven for rentier economies, this study investigates the perspectives and perceptions of policy makers and nonpolicy makers of a rentier economy of Saudi Arabia, the largest oil producer, towards investing its financial reserves, initially, in the financial sector and, particularly fixed-income securities. Furthermore, the study explores experts' views in regard to the optimal alternative to the investment in an financial sector. The outcomes of this research methods: interview and questionnaire, show that, despite the uncertainty and instability featured the present financial investment scene, manifested by the current economic slowdown and financial crisis: balance sheet recession, market crunches and banking collapse in different parts of the world, the majority of the participants, trusted the financial sector as a shelter for the reserves of Saudi Arabia. They believed that government bonds and T-bills are the most secure financial instruments to invest the accumulated revenues from oil returns. Thus, from the participants responses, the financial investment sector represents the acceptability framework that can be a safe channel to maximize income for the national economy.
\end{abstract}

Keywords: Safe haven; Rentier economy; Foreign securities; Fixed-income instruments; Uncertainty; Reserves; And foreign portfolio investment (FPI).

(c) () CC BY: Creative Commons Attribution License 4.0

\section{Introduction}

During the last three decades, foreign financial investment has been considered as a substantial focus across the national concerns of countries, due to the profitability that can be achieved. Recently, rich developing countries heavily invest huge amounts of their reserves in financial securities, particularly low risk and risk-free financial instruments.

The major theories in the financial economics argue that uncertainty and instability are fundamental features of the financial investment. In the heart of their views, financial investment is a world of uncertainty, instability and incalculable risk. Theories by key economists such as Knight (1921), Keynes (1936), Ellsberg (1961), Minsky (1978) and Mishkin (1997), have put and explained different causes behind the riskiness of the financial environment.

The issue of the optimal investment decision raises a growing concern for country investors that rely on one natural resource, like oil or gas. The objective of this paper is to provide experiential evidence on acceptability of a rentier economy such as Saudi Arabia to invest the reserves in foreign bonds and T-bills in addition to investigate the best alternatives rather than financial sector.

This study starts with a background overview of foreign financial investment as form of international investment, followed by a review of previous theories that connect uncertainty and instability factors with financial investment. Then the methods and data of questionnaire and interviews are explained demonstrating the outcomes of results. The findings is presented followed by the conclusion.

\section{Literature Review}

Financial investment that targets foreign securities for governments and institutions has taken different names. In some literature, investment by countries or private institutions is considered as Foreign Portfolio Investment (FPI). This type of investment initially returns to the 1960s, when United States and other investors actively began to invest in foreign securities markets (Gilmorea and McManusb, 2002).

Due to the development and fast growing of the financial markets and products, the investment in this sector has been widely regarded as a source for growing wealth and maximising returns. The United Nations (1999) has pointed out that a FPI can include investment in financial instruments such as securities issued by governments (e.g. sovereign bonds). Within this framework, foreign portfolio investment (FPI) has recently become a distinct form of capital inflow for developed countries (Humanicki et al., 2013). Empirical studies including Grubel (1968) and Levy and Sarnat (1970) indicate that holding foreign securities have led to reduction in risk and the increase of benefits.

Government bonds and T-bills are the most secure financial instruments, and thus considered the most attractive investment tools for investors. A body of research including studies by Ibbotson et al. (1982), Levy and Lerman (1988) have proved that investment in U.S bonds clearly produced substantial benefits and reduced the risk of the expected return for an international portfolio. However, Fama and French (1989) claimed that bonds adversely react 
to poor economic and business conditions but they indicated that high expected return must be induced the investment.

Development of bond markets provides important benefits for the economy. The World Bank and International Monetary Fund (2001), that securities issued by a government create an avenue for domestic funding of budget deficits other than that provided by the central bank. The existence of such bond markets could, additionally, help governments reduce their exposure to interest rate, currency fluctuations and other financial risks.

The bonds issued by the government are considered as the backbone of most fixed-income securities markets, in both developing and developed economies. According to The World Bank and International Monetary Fund (2001), bonds are backed by 'faith and credit' of the state, not by financial or physical assets. Martellini et al. (2003), point out that the securitised bonds are used for financing infrastructure and development projects, and thus they constitute a major part of bond markets.

The uncertainty and instability characteristics of the financial sector are key distortions in the financial investment regime. In the last century, the global crises in the world has been strongly linked to the financial disasters. Around a century ago, the extensive financial crises that collectively led to the great crash of 1929 were actually consequences of the developing financial systems in the industrialised nations of Britain, the USA and other European countries in the nineteenth and early twentieth centuries.

In the founding literature since Knight (1921), the focus is mainly on the key theories that support the nature of the uncertainty, instability and unpredictability in regard to the financial investment. The aspect of the uncertainty linked with financial investment was raised almost a hundred years ago. According to Rigotti and Shannon (2005), uncertainty raises conflicts that investors might fail to accommodate. Uncertainty is defined by Ellsberg (1961) as an event which is associated with an unknown probability. According to Keynes (1936), the complete set of information that an optimal investment decision requires - the potential return from each investment project - is not available and hence, cannot be taken into account at the point of decision-making. Davidson (1991), claims that probability cannot be used as a fundamental instrument to forecast the expected values of economic variables.

Arestis et al. (2012), point out that financial bubbles originate from increasing speculation, which is a result of the lack of regulation on financial activities and assets. Rising uncertainly implies the failure to anticipate the future. This is in line with the Keynesian literature which suggests that investment decisions have to be made under uncertainty and lack of perfect information. He suggests that the future is an end result of the decisions taken by economic agents in the present and future, which again cannot be foreseen. However, investment and portfolio decisions have to be made by corporations and investors who are subject to the dilemma that Keynesian uncertainty generates (Crotty, 1994).

The effects of uncertainty on investment have been identified through theoretical and empirical research. Aistov and Kuzmicheva (2012), concludes that financial investment is negatively exposed to the influence of uncertainty. According to Bansal and Yaron (2004), uncertainty reduces equity prices via effects on long-run growth. Bekaert et al. (2009), claim that the counter-cyclical volatility of asset returns emerges from uncertainty. Differentiating between good and bad credit risks has become difficult to predict for lenders, due to the growing prevalence of uncertainty factors in the financial markets (Mishkin, 1997).

Another feature that supports the uncertainty of the financial sector, among them bonds instruments, is instability. The Financial Instability Hypothesis (FIH) is an interpretation of the substance of Keynes's General Theory (Minsky, 1992). Since Keynes (1936), it has been pointed that the instability of financial investment decisions comes from the characteristic of human nature that relies more on 'spontaneous optimism rather than on mathematical expectation. The economist Minsky (1985) stating that the incautiousness of borrowers and lenders during phases of economic prosperity leads to incessant financial crises. As an outcome of the capitalist system, Minsky (1978), claims that financial markets pave the way for crises due to the involvement in risky credit frameworks.

Furthermore Mishkin (1997), claims that among the reasons causing instability are political disturbance, the collapse of the stock markets and the asymmetry of information in the financial markets. Asymmetric information analysis provides four main causes of financial instability: increases in interest rates, increases in uncertainty, asset market effects on balance sheets and problems in the banking sector. Mishkin (1997), proclaims that financial instability stems from intervention from shocks into the financial system, which deviate the channel of funds from investment opportunities. Evans (2009), points out that uncertainty about the future has led the major central banks to introduce internationally-coordinated exercises in which they prepare beforehand for any drastic financial collapse. Banks and other financial institutions have subjected themselves to highly risky investment positions in anticipation of higher returns.

The development of financial products is claimed to be one of the main drivers behind uncertainty and instability aspects Highly leveraged activities of hedge funds and private equity funds is clear example for risk attained in addition to the credit market which gives way to financial crises. Barnes (2010), concludes that the last financial crisis of 2007-2009 resulted in a reduction of investors conviction regarding investments and high return prospects due to which investment schemes were subject to pressure.

Furthermore, Tapiero (2010), indicates some risk factors that can be clearly noticed in the financial field, pointing that globalisation and interconnectedness in the investment world have increased the growth of risk. The influential role of larger financial institutions to widely promote new financial products together with the growth of financial information technology have contributed in risks rise. Lots of prevalent risks are obvious today, in or out of the financial world. The terrorist attack in 2001 has been considered, for instance, as a major challenge that 'questioned the possibility of seeing future risk as a mirror of past events' (Petersen, 2011). In conclusion, uncertainty 
and instability lead to financial disasters and presence of risk everywhere in financial investment instruments. This risky environment of threats test the risk-management calculus scheme and the models of exposure analysis and also the secure choice to invest the wealth of reserves for a rentier economy in such world.

\section{The Case of Saudi Arabia}

\subsection{Saudi Government Investor}

Foreign portfolio investment (FPI) has been a growing concern for governments of developing countries. Global markets have become more integrated and accessible due to the propensity towards liberalisation and market deregulation in the capital sectors in both developed and developing countries. FPI can promote sustainable growth to both industrialised and developing economies (Evans, 2002).

Nevertheless, the investment in a foreign portfolio of financial securities by developing countries which are reliant on one natural source for their national income, is questionable matter. Kingdom of Saudi Arabia will soon become one of the largest financial investors in the globe. This was officially announced by the Saudi government in 2016 among its transformational vision. The last decade witnessed the most prosperous times of oil prices in history, which led to vast amounts of petro-dollar revenues.

As a rentier economy, Saudi Arabia is heavily dependent on oil revenue as the main source of income. Saudi Arabia announced the vision 2030 to reduce reliance on oil, however the economy is completely based on the oil returns. It is the largest exporter of petroleum and the main leading member of the Organization of Petroleum Exporting Countries (OPEC). Oil represents excess of $85 \%$ of the total income. International institutions have ranked the Saudi Arabian economy as the world's 12th largest exporter of goods, the 22nd largest importer, the 21st largest service importer and the 33rd largest service exporter in the world (Ministry of Commerce and Investment, 2016). Lately it has become a member of the twenty largest economies (20G). Nevertheless, the kingdom is still counted as a developing country and a 'hostage' to changes in the oil prices (Albassam, 2015).

Towards achieving the goal of protecting the national wealth via growing the reserves, investment in foreign bonds has been actively implemented. According to Alsweilem (2015), the policy of financial investment has continued since 2000s despite the financial crisis 2008. The investment patterns of Saudi Arabian Monetary Agency (SAMA) - central bank- have remained largely unchanged as conservative attitude of a high exposure to fixed income but has not engaged with 'any direct investments, exotic financial products or real estate' (Alsweilem et al., 2015).

\subsection{Diversification Strategy}

Believing that the dependence on one source of income is a risky strategy and makes the economic national security vulnerable, Saudi chooses the transition away from an economy founded on oil returns to a new strategy for development, such as a knowledge-based economy (Al-Filali and Gallarotti, 2012). Saudi Arabia will face troubled times and a hard economic future if they do not implement serious steps towards diversification of their economies. Alghamedi (2014), points out that oil is a finite resource and that the high demand will be reduced over time due to the emergence of on-going alternative energy sources.

Despite all the efforts to diversify this rentier economy in the last twenty years, especially by promoting the nonoil sectors, such as exploring the natural gas, telecommunications and petrochemical sectors (Samargandi et al., 2014), Saudi Arabia has indulged in investing accumulated savings in the securities markets. Nevertheless, (Özyavuz and Schmid, 2015) claim that one of the problematic issues currently occurring in countries such as Saudi Arabia is the belief that financial investment in foreign financial sectors is a strategy to reduce the dependency on oil and maximise the reserves. Oil rich countries prefer investments that are quickly profitable, in order to decrease their reliance on oil revenue by creation of sovereign wealth funds as instrument to diversify their rentier economies (Özyavuz and Schmid, 2015).

Recently, there has been a plan to set up the largest investment fund in the world, in order to invest the reserves in financial securities and equities around the globe. In April 2016, Saudi Arabia announced its vision for establishing the largest investment fund amounted by $\$ 2$ trillion in order to help the country wean off reliance on oil (Micklethwait et al., 2016). Table No. 1 explains the amounts of financial investment of Saudi government since 2007. 
Table-1. The investment of Saudi Arabia in foreign Financial instruments

\begin{tabular}{l|l|l|l|l}
\hline Year & $\begin{array}{l}\text { foreign } \\
\text { securities } \\
\text { (\$ U.S dollar) }\end{array}$ & $\begin{array}{l}\text { Change } \\
\text { \% }\end{array}$ & $\begin{array}{l}\text { Debts } \\
\text { securities } \\
\text { (\$U.S dollar) }\end{array}$ & $\begin{array}{l}\text { Change } \\
\%\end{array}$ \\
\hline $\mathbf{2 0 0 7}$ & 210.8 & - & 52.2 & - \\
$\mathbf{2 0 0 8}$ & 307.7 & 31.4 & 48.3 & -8.07 \\
$\mathbf{2 0 0 9}$ & 285.7 & -7.7 & 62.7 & 22.9 \\
$\mathbf{2 0 1 0}$ & 315.1 & 9.9 & 67.6 & 7.2 \\
$\mathbf{2 0 1 1}$ & 379.9 & 17.0 & 76.7 & 11.8 \\
$\mathbf{2 0 1 2}$ & 444.0 & 14.4 & 75.3 & -1.85 \\
$\mathbf{2 0 1 3}$ & 519.3 & 14.5 & 79.2 & 4.9 \\
$\mathbf{2 0 1 4}$ & 531.6 & 2.3 & 87.9 & 9.8 \\
$\mathbf{2 0 1 5}$ & 400.2 & -32.8 & 93.8 & 6.2 \\
$\mathbf{2 0 1 6}$ & 362.3 & -10.4 & 89.7 & -4.5 \\
$\mathbf{2 0 1 7}$ & 330.5 & -9.6 & 61.0 & -47 \\
$\mathbf{2 0 1 8}$ & $322.6 *$ & -2.2 & 73.1 & 16.5 \\
\hline
\end{tabular}

Note: Data are sourced from Saudi Arabian Monetary Agency (SAMA).

\section{Methods and Data}

\subsection{Qualitative: Analytical Tools}

For designing a survey for the study, two qualitative analytical tools are used: semi-structured interview and a structured questionnaire. Selection of the research methods are determined according to the needs of the researcher towards answering the question of the study (Fink and Kosecoff, 1985). The research design includes one major question, methods for gathering information, the population and simple techniques for analysing data (Kothari, 2004).

Since the purpose of this study is to explore the perspectives of policy makers and professionals ${ }^{1}$ in regard to the confidence of investing the nation's wealth in financial instruments, a qualitative methodology is suitable to approach answers to investigative this study question.

Burton (2007), confirms the need for more research of a qualitative nature in finance pointing out that it such work mirrors the ability of the methodology to generate unique and significant empirical insights. According to Creswell (2003), interview and questionnaire is an explanatory data collection instrument that allow participants to express their views and reflect their experience (Pandey and Pandey, 2015). The qualitative approach enables the researcher to explore reasons for certain behaviour and discover underlying motives. Furthermore, through such method, researchers can analyse why the participants hold certain opinions (Kothari, 2004). The questions' responses were statistically analysed one by one using simple percentage rates and thematic analysis to provide explanations.

\subsection{Interview Method and Rational}

In this study, all the questions investigated require subjective answers based on the experience and knowledge. In order to reach the answers, an exploratory research approach has been chosen to investigate practitioners' and policy makers' reflections in the field of financial investment and the economic impacts. This type of approach can reflect the essence of human experiences concerning a phenomenon, as described by participants in a study, indicating that understanding the "lived experience" marks phenomenology as a philosophy as well as a method (Creswell, 2003).

According to Pandey and Pandey (2015), interview approach can provide a subjective view on the social sciences such as economic issues. Phenomenological research instrument further can enrich the study by insider data about the security of investing a country's wealth in the financial sector and the other alternative choices for best use of the reserves.

As interview was designed to capture the experts' perspectives, the participants were 5 Saudi policy makers and government advisors in different financial institutions ${ }^{2}$. It is divided into two categories. The first 5 sub-questions were constructed in the form of semi-structured questions that required participants to choose an answer of (Yes, No or Neutral) and then justify the answer. The last sub-question was the second part that basically focused to sightsee the secure alternatives to financial sector.

\subsection{The Questionnaire Method and Rational}

The questionnaire was designed in a structured questions format that presented in an order from: general questions to specific to answer the issue of the study (Pandey and Pandey, 2015). To test the participants' views on acceptability of financial investment decisions, the questionnaire is composed of 20 questions. It was divided into

\footnotetext{
${ }^{1}$ Both surveys were addressed to and conducted by professional: officials, advisors, consultants and specialist academics in the fields of financial investment and economics.

${ }^{2}$ The government sectors and institutions experts belong to are the Saudi Capital Market Authority (CMA), the Shura Council (authority for consultation), The International Islamic Bureau for Economics and Finance and the Financial Committee of Saudi Chambers Council.
} 
two parts. The first one included 10 structured questions requiring to choose from Likert scale choices. The second part was composed of 10 structured questions to choose from textual responses. This approach aims to obtain straightforward answers to potential alternative investment for an oil dependent economy such as Saudi Arabia rather than foreign financial sector.

A total of 50 professional participants from different financial and economic institutions have contributed to this survey. The questions were drawn up on web-page. All targeted participants were contacted via an email attached with a link which directs them to the website of this e-survey when they accept to participate.

\section{The Results and Interpretation}

\subsection{Interview Results and Interpretation}

The study raises the questions about the perspectives of experts regarding the security of investing the national reserves in the financial sector in general, followed by a question about the confidence of foreign financial securities as safe haven, then a question regarding the shelter of risk-free/low risk instruments such as bonds and T- bills. Furthermore, the interviews' questions included the perceptions of experts in regard to diversification strategy such as setting up a Sovereign Wealth Fund (SWFs) as an independent body for the purpose of investing oil revenues in financial assets. It also investigates the financial sector as diversification policy. The table No. 2 below explains the five experts' views participated in the study.

Table-2. Expert's responses of investing financial reserves in financial securities

\begin{tabular}{|c|c|c|c|c|}
\hline No. & Factor & YES & NO & Neutral \\
\hline 1 & $\begin{array}{l}\text { Financial sector is a secure choice for Saudi rentier } \\
\text { economy? }\end{array}$ & 3 & 1 & 1 \\
\hline 2 & Foreign financial securities can be a secure choice? & 2 & $\mathbf{0}$ & 3 \\
\hline 3 & $\begin{array}{l}\text { Risk-free/low risk instruments: bonds and T-bills can be a } \\
\text { secure choice? }\end{array}$ & 3 & $\mathbf{0}$ & 2 \\
\hline 4 & $\begin{array}{l}\text { Financial sector is an income diversification policy for } \\
\text { national economy? }\end{array}$ & 4 & $\mathbf{0}$ & 1 \\
\hline 5 & $\begin{array}{l}\text { Setting up a SWT can be a diversification strategy for the } \\
\text { economy? }\end{array}$ & 4 & $\mathbf{0}$ & 1 \\
\hline
\end{tabular}

Note: All responses are received in full of five experts interviewed

According to interview results, the majority of interviewees believed that the financial sector is considered a secure channel for a single-source dependent economy to invest the oil revenues accumulated; $60 \%$ of the policy makers justified this position by indicating that financial investment includes risk-free financial products and also provides a diversified choices for the investors.

The second question aimed at determining the experts' views regarding their perceptions towards foreign securities in general, as secure choice for investing the budget surplus. Three interviewees (60\%) chose the neutral answer for this question. They justified their views by indicating that the nature of financial debt securities, as some, but not all, foreign financial securities are secure choices. Another reason provided was that uncertainty and financial instability are crucial factors before the decision is made to invest in such financial securities. In responding to this question, two policy-makers believed that financial securities can be a secure tool when diversifying through low risk and risk-free instruments. One of the experts emphasised the optimality of debt instruments that debt Securities generally are not negatively affected by the local business cycle, thus providing a hedging strategy against a downward domestic business cycle.

The purpose of third question is to explore the perspective of the policy-makers regarding investing reserves in low and risk-free foreign financial securities. Three of interviewees believed that low and free-risk securities are the most secure financial instruments. $40 \%$ of the interviewees chose the neutral option justifying their answer by the factor of uncertainty and avoiding 'put all the eggs in one basket'. Furthermore, it was suggested that the investments should not be concentrated in one country, such as the U.S. and also Islamic bonds (Sukuk) could be focused on the medium and low level of risk adopted by this type of financial product.

The Fourth question finds out to what extent the policy makers considered the investment of the reserves in the financial sector as a diversification policy for the income of the national economy. The majority of interviewees held the view that diversification should involve different classes of investment in order to protect the portfolio from any potential risks. They pointed out that risk-free and low-risk financial instruments could play an important part in a diversification policy for the investment of the Saudi revenues from the oil returns.

This question investigated the policy-makers' views regarding setting up sovereign wealth fund (SWF) as an independent body for the purpose of investing reserves. The majority of experts (80\%) thought that creating a SWF to manage the wealth of the Saudi economy could be a diversification strategy on the national economy management level. The major reason provided was that it could distribute the risk of instability and uncertainty of markets in the portfolio. This fund, according to the experts, could diversify the financial investment activities and thus, for example, obtain major stakes in successful companies in different sectors across different economies. The diversification of the fund's activities would reduce the risk and generate another source of income that might, in turn, help to reduce the dependence on oil. 
Aside from financial investment, the study explores policy maker's perception towards the secure economic alternative sectors for investing reserves obtained from the oil returns. Table No. 3 show the thematic ideas for the suggested substitutes of financial investment can be adopted by Saudi government.

Table-3. The alternative investment of financial sector suggested by policy maker

\begin{tabular}{l|l|l}
\hline $\begin{array}{l}\text { No. of policy } \\
\text { makers }\end{array}$ & No. of Responses & $\begin{array}{l}\text { Total } \\
(\boldsymbol{\%})\end{array}$ \\
\hline 5 & 5 & 100 \\
\hline Thematic results & \\
\hline Classification & Recommendation \\
\hline Generic & developing non-oil sectors e.g. trade, services etc. \\
\hline Human resource & manpower and entrepreneurship ideas \\
\hline Real Investment & $\begin{array}{l}\text { direct real investment e.g. real estate, industry and } \\
\text { manufacturing. }\end{array}$ \\
\hline IT & $\begin{array}{l}\text { high value-added activities e.g. information, high-tech, } \\
\text { solar tech. }\end{array}$ \\
\hline Industry & petrochemical sector \\
\hline Note: The table summarizes the most important ideas and examples mentioned in the interviews
\end{tabular}

Note: The table summarizes the most important ideas and examples mentioned in the interviews

In the second part of the interview, an open-ended question aimed to add new dimensions for the research investigation. Each policy-maker has provided different answers to the question regarding the optimal alternative rather than financial sector, However, there was unanimous agreement that the Saudi government should take advantage of the revenue obtained from the oil returns by developing the non-oil sectors. The interviewees expressed varied preferences for alternative economic sectors that could be a substitute of financial investment. Four main nonfinancial areas of investment were mentioned by the experts: human resources, direct real investment, IT activities and industry.

Two experts believed that revenues from oil should be directed to develop manpower in the professional field, via training and education with emphasis on entrepreneurship ideas. One of the interviewees thought that direct investment in real sectors are the best choice for employing Saudi financial reserves.

Among the recommendations provided by the experts were: establishing manufacturing works, factories, and investing in basic material and natural resource companies, trading and the service sector. One interesting answer was the suggestion to invest in IT particularly in high value-added activities such as information and communication technologies, in addition to solar and bio-technologies and high-tech companies.

\subsection{Questionnaire Results and Interpretation}

The survey is divided into two parts covering 20 questions. The first part included 10 questions aimed at exploring the respondents' perspectives towards investing Saudi reserves in the international financial sector, particularly low-risk and risk-free securities. In the second part of the survey composed of 10 questions, which basically investigated the preferable alternatives for investing the revenues in the non-financial sector. The answers to the first part of the questions and number of responses are shown in Table No.4 below:

Table-4. Participants' perspectives to invest the reserves in international financial sector

\begin{tabular}{|c|c|c|c|c|c|c|}
\hline No. & Factor & $\begin{array}{l}\text { Strongly } \\
\text { disagree }\end{array}$ & Disagree & Neutral & Agree & $\begin{array}{l}\text { Strongly } \\
\text { Agree }\end{array}$ \\
\hline \multicolumn{7}{|c|}{ Foreign financial risk-free instruments } \\
\hline 1. & $\begin{array}{l}\text { investing reserves in the financial sector can } \\
\text { be a secure choice }\end{array}$ & $\mathbf{0}$ & 9 & 14 & 20 & 7 \\
\hline 2. & $\begin{array}{l}\text { foreign financial securities can be a secure } \\
\text { choice }\end{array}$ & 3 & 8 & 18 & 19 & 2 \\
\hline 3. & bonds and T-bills can be a secure choice & 3 & 5 & 11 & 24 & 7 \\
\hline 4. & U.S. bonds and T-bills can be a secure choice & 5 & 10 & 14 & 18 & 3 \\
\hline 5. & $\begin{array}{l}\text { Non-U.S. bonds and T-bills can be a secure } \\
\text { choice }\end{array}$ & 3 & 11 & 20 & 14 & 2 \\
\hline \multicolumn{7}{|c|}{ Foreign financial securities as secure choice } \\
\hline 6. & $\begin{array}{l}\text { Diversified foreign securities can be a secure } \\
\text { choice }\end{array}$ & 1 & 4 & 5 & 19 & 21 \\
\hline 7. & $\begin{array}{l}\text { The domestic financial sector can be a secure } \\
\text { choice }\end{array}$ & 2 & 7 & 13 & 23 & 5 \\
\hline 8. & $\begin{array}{l}\text { The domestic bonds budget is a more secure } \\
\text { choice }\end{array}$ & 1 & 10 & 18 & 17 & 4 \\
\hline 9. & $\begin{array}{l}\text { Islamic bonds (Sukuk) are more secured } \\
\text { choice }\end{array}$ & $\mathbf{0}$ & 7 & 14 & 22 & 7 \\
\hline 10. & $\begin{array}{l}\text { Expanding local financial markets is more } \\
\text { secured }\end{array}$ & 1 & 4 & 13 & 27 & 5 \\
\hline
\end{tabular}

Note: Responses above represent the first 10 questions of the questionnaire and responses received in full of 50 participants 


\subsubsection{Results and Interpretation Part One}

To understand the acceptance of the participants towards investing Saudi revenues from the oil in the financial sector in general, the survey illustrates clearly that $54 \%$ of the participants agreed and strongly agreed to invest reserves in the financial sector considering this a secure choice for the Saudi economy. Questions 2 and 3 examined participants' views based on their experience and knowledge regarding the safety of investing the national wealth in the foreign financial. In the view of $42 \%$ of the participants agreed and strongly agreed with this proposition. However, a considerable number of respondents, $36 \%$, are neutral while $24 \%$ of participants did not believe that foreign financial sectors are a secure option. Concerning bonds and Treasury bills, the majority of participants (62\%) agreed and strongly agreed that those instruments are secure choices for investing the reserve.

This question 4-5 explored the participants' view regarding the target market of foreign debt investment, in particular U.S. and non-U.S. bonds. The majority of the respondents agreed that U.S. Central Bank's bonds and Tbills could be a secure choice for investing the reserve. In contrast, $40 \%$ of participants are undecided as to whether non-U.S. bonds and T-bills could be a secure choice.

The purpose implied in question 6 is to discover the perspectives of participants towards diversifying the portfolio through foreign securities. The results show that $80 \%$ of participants strongly agree and agree that diversification is the safest option. Question 7 to 9 are for international financial investment and designed to discover the respondents' views regarding investing the Saudi reserves in the domestic financial market. Responses of 56\% participants indicated that they trusted the local financial market as the secure choice for investing the reserves. As many as $64 \%$ of the participants believed that taking advantage of reserves to expand the local financial markets would be a more secure choice for the Saudi economy. Question 10 is intended to reflect the opinions about Islamic bonds. The results show that $58 \%$ of respondents agreed or strongly agreed in considering Islamic financial bonds as a secure alternative to the conventional bonds.

\subsubsection{Results and Interpretation Part Two}

The second group of the questionnaire contains 10 structured questions to choose from textual responses. This is to explore participants' perceptions towards investing reserves in foreign financial sector in general and narrow questions to be more specific as shown in Table No.5:

Table-5. Participants' responses for investing reserves in foreign financial free-risk instruments

\begin{tabular}{|c|c|c|c|c|}
\hline No. & Factor & Statement & responses & $\%$ \\
\hline & \multirow{3}{*}{$\begin{array}{l}\text { financial sector is } \\
\text { characterized by: }\end{array}$} & Uncertainty and instability & \multirow{3}{*}{$\begin{array}{l}37 \\
7 \\
6\end{array}$} & \multirow{3}{*}{$\begin{array}{l}74 \\
14 \\
12\end{array}$} \\
\hline \multirow[t]{4}{*}{1} & & Certainty and stability & & \\
\hline & & None of the above & & \\
\hline & \multirow{4}{*}{$\begin{array}{l}\text { financial securities } \\
\text { are featured by: }\end{array}$} & Incalculable risk instruments & \multirow{4}{*}{$\begin{array}{l}6 \\
14 \\
29 \\
1\end{array}$} & \multirow{4}{*}{$\begin{array}{l}12 \\
28 \\
58 \\
2\end{array}$} \\
\hline & & Calculable risk instruments & & \\
\hline \multirow[t]{4}{*}{2} & & Risky instrument but can be calculable & & \\
\hline & & None of the above & & \\
\hline & \multirow{4}{*}{$\begin{array}{l}\text { low/risk-free } \\
\text { securities: bonds } \\
\text { and T- bills are: }\end{array}$} & Calculable but under uncertainty risk & \multirow{4}{*}{$\begin{array}{l}8 \\
14 \\
14 \\
14\end{array}$} & \multirow{4}{*}{$\begin{array}{l}16 \\
28 \\
28 \\
28\end{array}$} \\
\hline & & Calculable but market instability risk factors & & \\
\hline \multirow[t]{4}{*}{3} & & Calculable but uncertainty and instability risk & & \\
\hline & & None of the above & & \\
\hline & \multirow{4}{*}{$\begin{array}{l}\text { uncertainty in the } \\
\text { financial } \\
\text { relates to: }\end{array}$} & Economic factors & \multirow{4}{*}{$\begin{array}{l}2 \\
8 \\
3 \\
37\end{array}$} & \multirow{4}{*}{$\begin{array}{l}4 \\
16 \\
6 \\
74\end{array}$} \\
\hline & & Political factors & & \\
\hline \multirow[t]{4}{*}{4} & & Regulation factors & & \\
\hline & & All the above & & \\
\hline & \multirow{4}{*}{$\begin{array}{l}\text { budget reserve can } \\
\text { be secured to invest } \\
\text { in: }\end{array}$} & Diversified basket of high and low risks & \multirow{4}{*}{$\begin{array}{l}29 \\
14 \\
0 \\
7\end{array}$} & \multirow{4}{*}{$\begin{array}{l}58 \\
28 \\
0 \\
14\end{array}$} \\
\hline & & Securities with low risk and low return & & \\
\hline \multirow[t]{4}{*}{5} & & Securities with high risk and high return & & \\
\hline & & None of The above & & \\
\hline & \multirow{4}{*}{$\begin{array}{l}\text { The reserves is } \\
\text { supposed to be } \\
\text { employed for: }\end{array}$} & Diversifying economy income & \multirow{4}{*}{$\begin{array}{l}21 \\
1 \\
3 \\
25\end{array}$} & \multirow{4}{*}{$\begin{array}{l}42 \\
2 \\
6 \\
50\end{array}$} \\
\hline & & Expansion oil and other related sectors & & \\
\hline \multirow[t]{3}{*}{6} & & Saving as reserves & & \\
\hline & & All the above & & \\
\hline & \multirow{3}{*}{$\begin{array}{l}\text { The reserve can be } \\
\text { secured to be } \\
\text { invested in: }\end{array}$} & Direct investment in the real economy & \multirow{3}{*}{$\begin{array}{l}38 \\
6 \\
6\end{array}$} & \multirow{3}{*}{$\begin{array}{l}76 \\
12 \\
12\end{array}$} \\
\hline \multirow[t]{3}{*}{7} & & Investment in the financial industry services such & & \\
\hline & & Other & & \\
\hline & \multirow{4}{*}{$\begin{array}{l}\text { The reserve can be } \\
\text { secured to be } \\
\text { invested in: }\end{array}$} & Domestic real economy & \multirow{4}{*}{$\begin{array}{l}9 \\
2 \\
6 \\
33\end{array}$} & 18 \\
\hline 8 & & Regional real economy & & 4 \\
\hline & & Foreign real economy & & 12 \\
\hline & & All the above & & 66 \\
\hline & The reserve can be & Infrastructure development & 12 & 24 \\
\hline & secured to invested & Human resource development & 9 & 18 \\
\hline
\end{tabular}




\begin{tabular}{|c|c|c|c|c|}
\hline \multirow[t]{5}{*}{9} & \multirow[t]{4}{*}{ in: } & Agriculture & \multirow{4}{*}{$\begin{array}{l}0 \\
16 \\
2 \\
11\end{array}$} & \multirow{4}{*}{$\begin{array}{l}0 \\
32 \\
4 \\
22\end{array}$} \\
\hline & & Manufacturing (Industry) & & \\
\hline & & Trade and Business & & \\
\hline & & Technology and knowledge-based investment & & \\
\hline & \multirow{4}{*}{$\begin{array}{l}\text { The reserve } \\
\text { investment decision } \\
\text { should consider: }\end{array}$} & The national security & \multirow{4}{*}{$\begin{array}{l}2 \\
2 \\
3 \\
43\end{array}$} & \multirow{4}{*}{$\begin{array}{l}4 \\
4 \\
6 \\
86\end{array}$} \\
\hline \multirow[t]{3}{*}{10} & & The economic security & & \\
\hline & & The national wealth protection purposes & & \\
\hline & & All the above & & \\
\hline
\end{tabular}

Note: The number of participants are 50 and all their choice answers are received in full

This question initially explored the most characteristic aspect of the financial sector, in the eyes of the participants. The majority of participants $(74 \%)$ believed that uncertainty and instability are the essential features of financial markets. In question 2 , the aims is to examine the views of participants regarding financial securities. The results show that $58 \%$ of the respondents believed that financial securities are risky tools but could be calculable. In more specific, question 3 determines participants' views about low-risk and risk-free securities. An equal percentage of participants $28 \%$ believed that bonds and $\mathrm{T}$ - bills are calculable instruments but still featured market by uncertainty and instability risk.

In the light of understanding the basis of the claim of this research, question 4 investigated the factor that could be the reason behind the uncertainty of the financial sector, in the eyes of participants. The majority of participants $74 \%$ related uncertainty to a mix of different factors among them are economic, political and regulatory factors. Furthermore, to determine the acceptable level of risk towards decisions of investing Saudi reserves in the financial sector, question 5 aims to reflect the views of participants regarding the degree of risk that can be borne by the Saudi reserve. The survey illustrates that $58 \%$ of responses supports to diversify the financial securities basket with high and low risks.

Question 6 explores the goal of investing the reserves in financial instruments. Half of the respondents thought that the reserve investment decision should take into consideration dimensions of income diversification and increasing investment in the oil-related sector, to enhance this field, and should also aim to save part of the revenues as reserves. In question 7 , the investigation upon the participants' views about the security of the options to invest national wealth obtained from the oil returns, shows that $76 \%$ of participants supported direct investment of the reserves in the real economy.

Aside from the financial sector, the question 9 discovers the most secure area of investment in the real economy. The majority of respondents chose all the zone options in the real economy: domestic, regional and foreign real economies. Question 9 aims to examine further the most secure sector of choice for the participants. The manufacturing and industry sector was rated as the most preferred of the selected options; with 32\%. Final question seeks participants' perspectives towards the consideration of investing financial reserves in Saudi Arabia. As shown, $86 \%$ of the responses believed that essential considerations should be taken into account, i.e. national, economic security, and wealth protection.

\section{Findings: Interviews and Questionnaire}

The purpose of this research is to identify the perspectives of policy makers and non-policy makers in the rentier economy of Saudi Arabia regarding investing the central bank reserves in the financial sector, and also in risk-free tools such as government bonds and T-bills. Remarkably, in contrast to the key theories of financial investment and current empirical findings, and despite the current financial crisis effect and economic recession, the majority of participants in both qualitative methods employed in this study chose foreign financial instruments, particularly bonds and T-bills, as a secure option for growing the accumulated wealth of Saudi economy. However, this finding is followed by a strong tendency of the respondents to suggest investing a proportion of these huge reserves in the local financial markets and in a different versions of domestic bonds, such as Islamic Sukuk.

The results also showed a high consistency of participants' answers and choices between policy makers and nonpolicy makers. In their answers to the key questions of this research, both sides also showed very closely matched responses for the majority of the choices. For example, $60 \%$ of both approaches' participants have strongly supported bonds and T-bills as a safer investment resort for Saudi economic wealth. In contrast, both interviewees and survey questionnaire participants did not favour other foreign financial securities for investing Saudi reserves, citing uncertainty and instability as threatening factors.

Figure No.1 shows the perceptions of participants in the interview and survey towards investing reserves in financial sector.

Figure-1. Perspectives in both surveys: expert interview and questionnaire

\begin{tabular}{l|l|l|l}
\hline Participants & The financial Sector & Foreign financial securities & Bonds and T-bills \\
\hline Policy makers & $60 \%$ & $40 \%$ & $60 \%$ \\
\cline { 1 - 3 } Non-Policy makers & $54 \%$ & $42 \%$ & $62 \%$ \\
\hline \multicolumn{2}{l|}{} \\
\hline
\end{tabular}




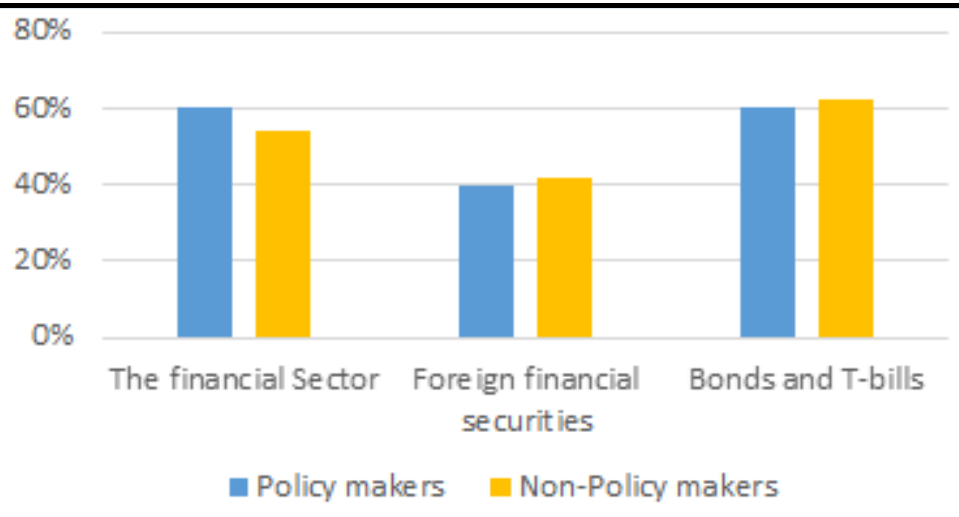

Note: The percentage meant to represent perspective responses towards acceptability of financial sector as safe resort

In addition, there is an agreement between policy makers and non-policy makers on two points. The first one is the importance of adopting a policy of portfolio diversification in financial investment, focusing on the aspect of low risk. The second is the importance of adopting a strategy to engage with the real economy sectors in the investment plan of oil revenues, particularly the industrial sector and high-tech innovation, along with human resource development.

\section{Conclusion}

In this study, interviews with policy makers and a structured questionnaire conducted with specialist (academics and professionals) have shown the support to invest Saudi financial reserves in the foreign financial sector. Although the respondents indicated to uncertainty and instability features of the financial system, they believed that bonds and T-bills, due to being calculable risk tools, can be a secure choice for Saudi financial wealth.

The participants from both surveys advocate persevering a strategy of investing oil revenue reserves in instruments such as risk-free foreign bonds and T-bills. On the other hand, some respondents recommended the domestic financial markets as the best choice for the government to invest the accumulated reserves. Real economy sectors are also strongly recommended by interviewees and survey participants as another alternative in which to invest the oil revenues, particular in industry, and the fields of infrastructure and technology.

Figure No.2 concludes the acceptability framework from participants' perceptions of both surveys: interview and questionnaire; towards employing financial reserves of a rentier economy such as Saudi Arabia in the international financial sector. From participant perspectives, investing reserves in the foreign financial sector, specifically low and free-risk instruments present a successful channel for maximizing the national returns and hence, existing a new source of income for this rentier economy.

Figure-2. The framework of acceptability to invest reserves in low and free-risk foreign financial investment

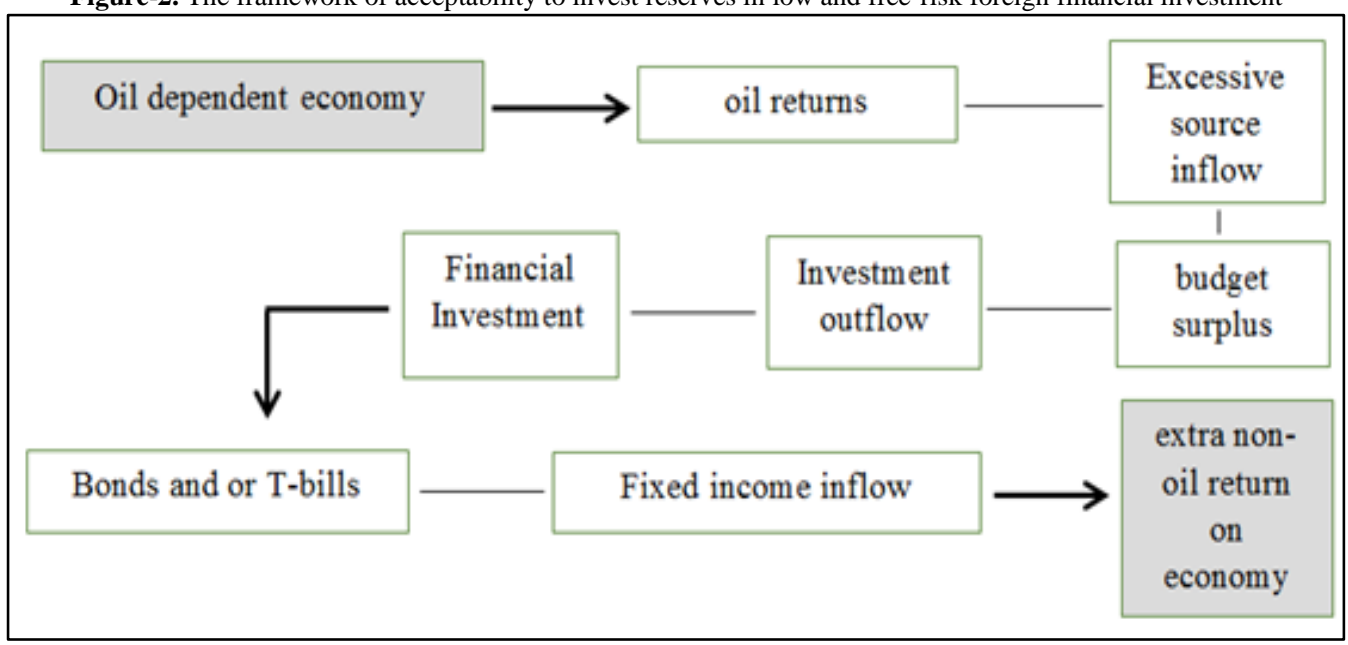

\section{References}

Aistov, A. and Kuzmicheva, E. E. (2012). Investment decisions under uncertainty: Example of russian companies', in lehner, o. And losbichler, $h$. (ed.) finance and risk perspectives. 1st ednEnns: Australia.

Al-Filali, I. Y. and Gallarotti, G. M. (2012). Smart development: Saudi arabia's quest for a knowledge economy. International Studies, 49(1-2): 47-76. Available: http://isq.sagepub.com.ezproxy.kingston.ac.uk/content/49/1-2/47.full.pdf+html

Albassam, B. A. (2015). Does Saudi Arabia's economy benefit from foreign investments? Benchmarking: An International Journal, 22(7): 1214-28. Available: http://www.emeraldinsight.com/doi/pdfplus/10.1108/BIJ$\underline{\text { 05-2014-0039 }}$ 
Alghamedi, A. (2014). Lack of diversification is a challenge facing saudi arabia. Journal of Global Business Issues, 8(2): 57-62. Available:

http://search.proquest.com.ezproxy.kingston.ac.uk/docview/1654944547/fulltextPDF/6C90733168FB40CF $\underline{\mathrm{PQ} / 1 \text { ? accountid }=14557}$

Alsweilem, K. (2015). A stable and efficient fiscal framework for saudi arabia: A role for sovereign funds in decoupling spending from oil revenue and creating a permanent source of income. Belfer Centre for Science and International Affairs and Centre for International Development, Harvard Kennedy School. http://belfercenter.ksg.harvard.edu/files/Saudi.pdf

Alsweilem, K., Cummine, A., Rietveld, M. and Tweedie, K. (2015). A comparative study of sovereign investor models: Sovereign fund profiles. 1st edn: Belfer Centre for Science and International Affairs: New York. http://projects.iq.harvard.edu/files/sovereignwealth/files/fund_profiles_final.pdf

Arestis, P., González, A. R. and Óscar, D. O. (2012). Investment, financial markets, and uncertainty. Working paper No. 743. New York: The levy economics institute.

Bansal, R. and Yaron, A. (2004). Risks for the long run: A potential resolution of asset pricing puzzles. The Journal of Finance, 59(4): 1481-509.

Barnes, P., 2010. "Minsky’s financial instability hypothesis: Information asymmetry and accounting information." In An addendum: the financial crisis of 2007-9 in the UK. Proceed in The sixth Accounting History International Conference, Wellington, New Zealand 18 - 20 August 2010.

Bekaert, G., Engstrom, E. and Xing, Y. (2009). Risk, uncertainty, and asset prices. Journal of Financial Economics, 91(1): 59-82.

Burton, B. (2007). Qualitative research in finance - pedigree and renaissance. Studies in Economics and Finance, 24(1): 5-12. Available: https://doi.org/10.1108/10867370710737355

Creswell, J. W. (2003). Research design: Qualitative, quantitative and mixed methods approaches. 2nd edn: Sage Publications: London.

Crotty, J. R., 1994. "Are keynesian uncertainty and macrotheory compatible? Conventional decision making, institutional structures, and conditional stability in keynesian macromodels in Dymski, G. and Pollin, R. (ed.)." In New Perspectives in Monetary Macroeconomics: Explorations in the Tradition of Hyman Minsky. USA: Ann Arbor. pp. 105-42.

Davidson, P. (1991). Is probability theory relevant for uncertainty? A post keynesian perspective. Journal of Economic Perspectives, 5(1): 19-43.

Ellsberg, D. (1961). Risk, ambiguity, and the savage axioms. Quarterly Journal of Economics, 75(4): 643-69.

Evans, 2002. "Foreign portfolio and direct investment: Complementarity, differences, and integration." In Global forum on international investment, attracting foreign direct investment for development, OECD and OCDE, Shanghai. pp. 5-6.

Evans (2009). Money and finance today, in grahl, J. (ed.) global finance and social europe. Edward Elgar: Britain. $1-28$.

Fama, E. F. and French, K. R. (1989). Business conditions and expected returns on stocks and bonds. Journal of Financial Economics, 25(1): 23-49. Available: http://wwwbcf.usc.edu/ christoj/pdf/OLD2/fama_french_1989.pdf

Fink, A. and Kosecoff, J. (1985). How to conduct surveys. 1st edn: Sage Publications: California.

Gilmorea, C. G. and McManusb, G. M. (2002). International portfolio diversification: US and Central European equity markets. Emerging Markets Review, 3(1): 69-83. Available: http://www.sciencedirect.com/science/article/pii/S1566014101000310

Grubel, H. (1968). Internationally diversified portfolios. American Economic Review, 58: 1299-314. Available: http://www.jstor.org/stable/pdf/1814029.pdf?_=1464212664629

Humanicki, M., Kelm, R. and Olszewski, K. (2013). Foreign direct investment and foreign portfolio investment in the contemporary globalized world: should they be still treated separately? Narodowy Bank Polski, NBP Working Paper No. 167. Warsaw: Poland. Available: https://www.nbp.pl/publikacje/materialy_i_studia/167_en.pdf

Ibbotson, R. G., Carr, R. C. and Robinson, A. W. (1982). International equity and bond returns. Financial Analysts Journal, 38(4): 61-83. Available: https://www.jstor.org/stable/pdf/4478566.pdf

Keynes, J. M. (1936). The general theory of employment, interest and money. Macmillan: UK. http://cas.umkc.edu/economics/people/facultypages/kregel/courses/econ645/winter2011/generaltheory.pdf

Knight, F. H. (1921). Risk, uncertainly and profit. Boston: USA.

Kothari, C. R. (2004). Research methodology: Methods and techniques. 2nd edn: New Age International Publishers: New Delhi.

Levy, H. and Sarnat, M. (1970). International diversification of investment portfolios. American Economic Review, 60(4): 668-75.

Levy, H. and Lerman, Z. (1988). The benefits of international diversification in bonds. Financial Analysts Journal, 44(5): 56-64. Available: https://www.jstor.org/stable/pdf/4479145.pdf? =1464200917032

Martellini, L., Priaulet, P. and Priaulet, S. (2003). Fixed-income securities: Valuation, risk management and portfolio strategies. 2nd edn: Wiley: Chichester. http://www.untagsmd.ac.id/files/Perpustakaan_Digital_1/FINANCE\%20Fixed-Income\%20Securities\%200470852771.pdf 
Micklethwait, J., Carey, G., Shahine, A. and Martin, M. (2016). Saudi Arabia plans $\$ 2$ trillion megafund for post-oil era: Deputy crown prince. Bloomberg. http://www.bloomberg.com/news/articles/2016-04-01/saudi-arabiaplans-2-trillion-megafund-to-dwarf-all-its-rivals

Ministry of Commerce and Investment (2016). About Saudi economy. Available: http://mci.gov.sa/en/AboutKingdom/Pages/SaudiEconomy.aspx

Minsky, H. (1978). The financial instability hypothesis: A restatement. Thames Papers in Political Economy: London: UK. http://digitalcommons.bard.edu/cgi/viewcontent.cgi?article=1179\&context=hm_archive

Minsky, H. (1985). The financial instability hypothesis: A restatement in: P Arestis and T Skouras (eds) Post keynesian economic theory. a challenge to neo classical economics. Sussex: Weatsheaf Books.

Minsky, H. (1992). The financial instability hypothesis: A restatement', levy economics institute of bard college, paper No. 74. New York: USA. Available: http://www.levyinstitute.org/pubs/wp74.pdf

Mishkin, F. S. (1997). The causes and propagation of financial instability: Lessons for policymakers in The Hole, J. (ed.) Maintaining financial stability in a global economy. The Federal Reserve Bank of Kansas City: Kansas. 55-96.

Özyavuz, A. and Schmid, D. (2015). Persistence and Evolutions of the Rentier state model in gulf countries, The Institute français des relations internationales (Ifri), Policy Paper, 23 April $2015 . \quad$ Available: https://www.ifri.org/en/publications/enotes/notes-de-lifri/persistence-and-evolutions-rentier-state-modelgulf-countries

Pandey, P. and Pandey, M. M. (2015). Research methodology: Tools and techniques. 1st edn: European Union: Romania. http://euacademic.org/BookUpload/9.pdf

Petersen, K. (2011). Risk analysis - A field within security studies? European Journal of International Relations, 18(4): 693-717. Available: file:///C:/Users/ACER/Downloads/Risk\%20analysis.pdf

Rigotti, L. and Shannon, C. (2005). Uncertainty and risk in financial markets. Econometrica, 73(1): 203-43.

Samargandi, N., Fidrmuc, J. and Ghosh, S. (2014). Financial development and economic growth in an oil-rich economy: The case of Saudi Arabia. Economic Modelling, 43: 267-78. Available: http://ejournals.ebsco.com/Direct.asp?AccessToken=95MQII18XDDE9IJ9RKIEQD1DMRIE8MQM4\&Sh ow=Object

Tapiero, C. S. (2010). Risk, finance and asset pricing: Value, measurements, and markets. 1st edn: Wiely: New Jersey. https://books.google.com.eg/books?id=UuWOkwic9AC\&printsec $=$ frontcover\&hl=ar\&source=gbs_ge summary $r \& c a d=0 \# v=$ onepage \&q\&f=false

The World Bank and International Monetary Fund (2001). Developing government bond markets, A handbook. Available: file:///C:/Users/nma1g14/Downloads/multi0page.pdf

United Nations, 1999. In United Nations Conference on Trade and Development Geneva: United Nations. 